\title{
CPV VIDEOSTUDIE TĚLESNÉ VÝCHOVY: SBĚR DAT A ZAMÝŠLENÉ ANALÝZY
}

\author{
MARCELA JANÍKOVÁ, TOMÁŠ JANÍK, \\ VLADISLAV MUŽÍK, VÁCLAV KUNDERA
}

\begin{abstract}
Anotace: V přispěvkuje představen metodologický postup CPV videostudie tělesnévýchovy, kterou realizuje Centrum pedagogického výzkumu PdFMU. CPV videostudie tělesné výchovy navazuje na CPV videostudii fyziky a CPV videostudii zeměpisu a probíhá současně s CPV videostudií anglického jazyka. V průběhu školního roku 2006/07 byly standardizovaným postupem pořizeny videozáznamy 58 vyučovacích jednotek $v$ predmětu tělesná výchova v 7. a 8. ročnících základních škol. Přispěvek predstavuje vybrané analýzy, jež budou provedeny $v$ průběhu let 2008-2010 (časové zastoupení organizačních forem výuky, fází výuky, používání didaktických prostředků a médií ve výuce, práce s reáliemi, príležitosti k osvojování jazykových dovedností a strategií učení).
\end{abstract}

Klíčová slova: časová dimenze výuky, obsahová dimenze výuky, videostudie, výuka tělesné výchovy, výzkum výuky

\begin{abstract}
The paper introduces the methodological procedure of the CPV video study of Physical Education that is being realised by the Educational Research Centre (CPV) of the Faculty of Education, Masaryk University. The project follows the CPV video study of Physics and CPV video study of Geography projects and coincides with the CPV video study of English project. In CPV video study of Physical Education, 58 lessons of Physical Education have been video recorded as taught in the 7th and 8th grades of Czech basic schools during the 2006/07 school year. The obtained data are being analysed, based on various general didactic and subject specific indices (temporal quantification of individual modes of classroom organisation and lesson phases, teaching styles, opportunities to talk, content of teaching and learning etc.).
\end{abstract}

Key words: video study, physical education teaching, instruction research, time dimension of instruction, content dimension of instruction

\section{1. Úvodem}

Pod zastřešujícím názvem CPV videostudie se od roku 2004 v Centru pedagogického výzkumu PdF MU realizuji výzkumy založené na analýze videozáznamů výuky v různých vyučovacích předmětech nižšího sekundárního vzdělávání: fyzika (Janík, Miková 2006), zeměpis (Hübelová, Janík, Najvar 2007), anglickýjazyk (Najvar, Najvarová 2007) a tělesná výchova (Miková, Janík 2007ab). CPV videostudie tělesné výchovy je realizována ve spolupráci Centra pedagogického výzkumu Pedagogické fakulty 
MU, Katedry pedagogiky sportu Fakulty sportovních studií MU a Katedry tělesné výchovy Pedagogické fakulty MU ${ }^{19}$. Zahraničním partnerem této videostudie je Institut pro vědy o sportu Univerzity v Salzburgu (Interfakultärer Fachbereich für Sport- und Bewegungswissenschaften). CPV videostudie tělesné výchovy byla zahájena počátkem roku 2007. Jejím teoretickým východiskem je pojetí vyučováníjako vytvářenípríležitostí k učení. Předmětem analýz jsou videozáznamy 58 vyučovacích jednotek tělesné výchovy (51 čtyřicetipětiminutových a 7 devadesátiminutových) pořizené v 19 školách u 20 učitelů na 2. stupni základních škol v Jihomoravském, Olomouckém a Zlínském kraji (náhodný výběr). Metodologický postup této videostudie byl zahraničnímu odbornému publiku představen v př́spěvku M. Mikové a T. Janíka (2006), česká odborná veřejnost s ním byla seznámena ve studiích M. Mikové a T. Janíka (2007ab).

Cílem předkládaného př́spěvku je podat přehled o koncepci $C P V$ videostudie tělesné výchovy, popsat její výzkumný design, představit zamýšlené analýzy v řadě obecně didaktických aspektů (např. organizační formy a fáze výuky) i oborově didaktických aspektů (např. didaktické ŕídicí styly, verbální projevy učitele) a prezentovat vytvářené kategoriální systémy. Výsledky CPV videostudie tělesné výchovy budou průběžně publikovány během let 2008-2010, tj. po dobu řešení projektu LC 06046 Centrum základního výzkumu školního vzdělávání, s jehož podporou je tato videostudie realizována.

\section{Stav řešené problematiky, teoretická východiska, cíle, otázky}

Zkoumání procesů vyučování a učení odehrávajících se ve výuce tělesné výchovy představuje rozvinutou oblast empirického výzkumu, a to jak u nás, tak zejména $\checkmark$ zahraničí. Různé modifikované metody nebo metody vytvořené výlučně pro potřeby výzkumu v tělesné výchově usilují o postižení konkrétních zvláštností tohoto vyučovacího předmětu. Podle Widmera (1976) totiž prokazuje interakční struktura vztahu učitel-žák zásadní rozdíly v oblasti organizační, výkonnostní, didaktické, ale i v oblasti lidských vztahů. $V$ tělesné výchově se žák navenek téměř neustále projevuje svým pohybovým výkonem, jen stěží může učební činnost předstírat, a přitom má velký význam i nonverbální a paralingvistická komunikace učitel-žák. Mluvené učitelovy projevy mají vysloveně instrumentální funkci a objevuje se i tělesný kontakt mezi učitelem a žákem (např. při dopomoci).

Rozsáhlá studie Piérona (2005) upozorňuje, že pozorování specifického učitelova chování ve výuce tělesné výchovy zahájili H. H. Anderson (1967) a W. Anderson (1975). Četné navazující výzkumy srovnávaly profil učitelových intervencí na různých stupních škol (Anderson, Barrette 1978; Piéron 1982), zkoumaly učitelovu expertní úroveň (např. Grant 1985) nebo učitelovu zkušenost (Freedman 1978). Dále bylo analyzováno reciproční chování učitele a žáků (Piéron 1982), specifičnost prostředí v tělesné výchově a jeho srovnání s prostředím $v$ naukových předmětech (Widmer 1976), vztah mezi zpětnou informací poskytovanou učitelem a odpově-

19 Videostudie prováděné CPV (Centrem pedagogického výzkumu PdF MU) jsou souhrnně nazývané CPV videostudie; $\mathrm{tj}$. CPV videostudie fyziky, CPV videostudie zeměpisu, CPV videostudie anglického jazyka a CPV videostudie tělesné výchovy. 
dí žáka (Doyle 1986). Silverman (1991) rozšíríl zkoumání učitele o činnosti konané před vyučovací jednotkou (plánování) a po jejím skončení (reflexe). Pozorování chování žáků přineslo mj. překvapující zjištění, že pohybové činnosti nejsou hlavním druhem projevu žáka (Costello, Laubach 1978; Piéron, Dohogne 1980). Proto se výzkum zaměřil také na rozdíly v chování žáků ve vztahu k učebním cílům, učivu nebo vyučovacím strategiím (např. Telama et al.1982). Byly také získány charakteristiky nejvíce a nejméně motivovaných žáků (Carreiro da Costa et al. 1997). Pomocí dotazníků byly zjištovány názory učitelů na to, co znamená dobrá vyučovací jednotka tělesné výchovy (Arrighi, Young 1987; Carreiro da Costa, Piéron 1992) nebo bylo analyzováno učitelovo myšlení v průběhu jeho rozhodování $v$ různých fázích výuky (např. Housner, Griffey 1985). Rozvinutou oblast dále představuje zkoumání didaktických řídicích stylů ve výuce tělesné výchovy (Kulinna et al. 2003; Cothran et al. 2005), které se rozvíjí v návaznosti na teorii spektra didaktických stylů (Mosston, Ashworth 2002). Realizovány byly také videostudie výuky tělesné výchovy (Curtner-Smith et al. 1995).

Počátky výzkumu činnosti učitele a žáků v české tělesné výchově spadají do 70. let minulého století (např. Šafaříková 1974; Dobrý 1975; Dobrý, Svatoň 1977). Kobjasnění významu a př́nosu zkoumání didaktické interakce pro didaktiku založenou na činnostním př́stupu vedla zejména práce Dobrého a kol. (1981). Technikou SPIN (Systematické pozorování interakce) autorů Svobody a Kocourka (1987) nebo technikou KSPV (Kategoriální posuzovací systém videozáznamu) autora Jansy (1987) byla posuzována struktura činnosti učitele a žáků. Bylo zjištěno, že nejčetnější činnosti učitele v tělesné výchově jsou instrukce, ukázka, pozorování a korekce. Metoda ADI (Analýza didaktické interakce), kterou vyvinuli Dobrý, Svatoň a Šafař́íková (1984), umožnila zdůvodňovat vztahy mezi kvalitou interakce učitel-žák a výsledky učení žáků. Popisný přístup byl tedy nahrazen vztahovou analýzou a pozornost se obrátila na výzkum vlivu zpětných informací nebo různých didaktických stylů učitele na kvalitu učební činnosti žáků. Byla rovněž zkoumána dynamika vyučovací a učební činnosti (Hurychová 1983; Matoušek 1984) i možnosti samostatného rozhodování žáků v různých didaktických stylech (např. Svatoň 1990). Navazující práce se zaměřily na ovlivňování vyučovací činnosti učitele pomocí zpětné informace (např. Mužík, Hurychová 1994), na ověrování uplatnění didaktických rrídících stylů ve výuce (např. Mužík 1997) nebo na vymezení činnostního profilu učitele a jeho profesních kompetencí (Karásková 1994).

$\checkmark$ posledních letech nejsou interakční výzkumy $v$ české tělesné výchově četné ani rozsáhlé a orientují se spíše na výuku specificky zaměřeného učiva, na vybrané formy chování učitele apod. (např. Süss, Matošková, Štefanšíková 2003). Častěji než observační techniky jsou využívány jiné výzkumné metody, např. dotazník k hodnocení vyučovací jednotky tělesné výchovy (Frömel, Novosad, Svozil 1999).

Jak je z výše uvedeného přehledu patrné, na rozdíl od konce minulého století je dnes u nás interakce učitel-žáci (procesy vyučování a učení v jejich provázanosti) ve výuce tělesné výchovy spíše opomíjeným výzkumným tématem. Přitom právě zkoumání toho, co se denně odehrává v desetitisících hodin tělesné výchovy ve školách, může napovědět mnohé o (procesuální) kvalitě těchto vyučovacích hodin. 
Potřeba proniknout k procesuální dimenzi výuky tělesné výchovy se stala výzvou $\mathrm{k}$ realizaci $C P V$ videostudie tělesné výchovy.

Teoretický koncept príležitosti k učení zastřešující CPV videostudii jako celek (viz Janík, Najvar 2008 v tomto čísle Orbis scholae) je třeba pro účely videostudie tělesné výchovy specifikovat. $\mathrm{V}$ obecném pohledu mají príležitosti k učení povahu určité výzvy podněcující žáky k tomu, aby se zabývali učivem, resp. učebními úlohami. Ve snaze zkoumat, jaké přiležitosti $k$ učení se žákům ve výuce jednotlivých vyučovacích předmětů nabízejí, přistupujeme $\mathrm{k}$ operacionalizaci konceptu príležitosti $k$ učení ve dvou ohledech:

- Přiležitosti k učení jsou sledovány z obecně didaktického pohledu - pozornost je zaměřena na obecnější aspekty výuky (např. organizační formy a fáze výuky) jdoucí napříč kurikulem základního vzdělávání. Obecné aspekty výuky jsou kódovány s využitím kategoriálních systémů pokud možno tak, aby bylo možné data za jednotlivé vyučovací předměty systematicky porovnat (komparativní př́stup k jednotlivým vyučovacím předmětům v kurikulu základního vzdělávání jako celku). $Z$ obecně didaktického hlediska videostudie směřují $k$ identifikaci toho, $v$ čem si jsou jednotlivé vyučovací předměty podobné.

- Přiležitosti $k$ učení jsou sledovány z pohledu didaktiky tělesné výchovy - pozornost je zaměřena na specifické oborově didaktické aspekty výuky: jedná se např. o uplatnění didaktických řídicích stylư²0, o vytváření přiležitostí k motorickému, sociálnímu a kognitivnímu učení (např. rozvíjení pohybových dovedností - průpravná cvičení, manipulace s míčem; prostor pro sociální učení - skupinové hry, fair play; zprostředkování teoretických znalostí - herní pravidla, znalost účinku pohybových aktivit na zatížení svalů, zdravotní benefity). Tyto aspekty umožňují zohlednit specifické rysy výuky v různých vyučovacích předmětech vyplývající z odlišnosti učiva. Pro oborové aspekty výuky budou vytvářeny a ověřovány speciální kategoriální systémy a škály. Z oborově didaktického hlediska videostudie směřují k identifikaci toho, čím je tělesná výchova jako vyučovací předmět specifická.

CPV videostudie jednotlivých vyučovacích předmětů jsou zastřešeny společným výzkumným cílem, který spočívá v realizaci explorativní analýzy procesů vyučování a učení odehrávajících se ve výuce. Záměrem je dokumentovat, popsat a analyzovat tyto procesy ve výuce jednotlivých předmětů v základních školách a vypracovat tak východiska pro jejich kontinuální zkvalitňování. CPV videostudie tělesné výchovy je součástí obecného konceptu. Proto respektuje na jedné straně obecná východiska CPV videostudie jako celku, na druhou stranu se opírá o východiska specifická pro tělesnou výchovu.

V CPV videostudii tělesné výchovy budou hledány odpovědi na výzkumné otázky, jako jsou např.: $V$ jakých organizačních formách se odehrává výuka tělesné výchovy? V jakých fázích se odehrává výuka tělesné výchovy? Jaké je zastoupení orga-

20 Přestože byl pojem didaktický ř́dicí styl (teaching style) původně operacionalizován pro tělesnou výchovu (Mosston, Ashworth 2002; Dobrý 2007), Ize kolem něj rozvinout empirický výzkum i v jiných vyučovacích předmětech. Zahrnuje totiž souvislosti mezi obecnějšími didaktickými kategoriemi: cíl-učivo-žák-učitel. 
nizačních forem v jednotlivých fázích výuky? Jaké didaktické styly se uplatňují ve výuce tělesné výchovy? Jaké didaktické funkce plní učitelovy verbální projevy? Jak je ve výuce tělesné výchovy zprostředkováván vzdělávací obsah? Jaké přiležitosti k získávání znalostí jsou žákům ve výuce tělesné výchovy nabízeny?

\section{Metodologický postup}

Zahraniční metodologické prístupy ke zkoumání výuky tělesné výchovy jsou popsány v přehledové práci Darsta a kol. (1983), nověji k tomu viz přehledová studie Warda a Baretta (2002). Také u nás byly vytvořeny deskriptivně analytické systémy ${ }^{21}$ umožňující postihnout jevovou stránku činností učitele a žáků ve výuce tělesné výchovy - zmiňujeme následující:

- Metoda ADI - Analýza didaktické interakce (Dobrý et al. 1997) je založena na přímém pozorování interakce učitel-žák ve vyučovací jednotce. Vyučovací jednotka je zaznamenána na magnetofon a paralelně k tomuto záznamu jsou na magnetofon zaznamenávány poznámky pozorovatele. Kategoriální systém obsahuje 9 kategorií a 78 subkategorií. Kategorie vymezují formy chování učitele; formy chování žáka nebo skupiny žáků ve funkci/roli, do níž byl žák delegován učitelem; formy projevu učitele; postojovou aktivitu učitele a míru vyjádření věcného obsahu; druh činnosti, která je předmětem didaktické interakce; činnost žáka, skupiny a celé třídy, determinující současně vztah učitele k ostatním účastníkům didaktického procesu. Kódování probíhá v pětisekundových intervalech.

- Technika SPIN - Systematické pozorování interakce (Svoboda, Kocourek 1987; Mužík, Uhlír 1989) slouží pro informaci o struktuře činnosti učitele a o charakteru činností žáků. Zahrnuje 13 kategorií činnosti učitele a 7 kategorií činnosti žáků. Kóduje se v pětisekundových intervalech. Za problematickou je považována identifikace jednoslovných projevů učitele a neverbálních projevů.

- Základem KPSV - Kategoriálního posuzovacího systému videozáznamu (Jansa 1981), který byl vyvinut pro potřeby zkoumání činnosti učitelů a žáků na 1. stupni ZŠ, je pět nejčastěji se opakujících vyučovacích činností učitele tělesné výchovy. Jedná se o instrukci, ukázku, předcvičování, sledování, korekci. Kódování probíhá na základě videozáznamu v desetisekundových intervalech.

Vedle výše uvedených čerpal metodologický prístup CPV videostudie tělesné výchovy inspiraci také ve videostudiích TIMSS, IPN a dalších (Janík, Najvar v tomto čísle Orbis scholae). Byla snaha stavět na dobrých zkušenostech domácích i zahraničních, na přistupech koncipovaných adresně pro výzkum výuky tělesné výchovy i na přístupech, které byly vytvořeny pro výzkum výuky v jiných vyučovacích předmětech.

\subsection{Výběr vzorku - popis zkoumaného souboru - sběr dat}

$C P V$ videostudie tělesné výchovy probíhala paralelně s CPV videostudií anglického jazyka (Najvar a kol. v tomto čisle Orbis scholae). Z tohoto důvodu jsou postupy uplatně-

21 Metodologickými problémy analýzy (intermitentní) pohybové aktivity se zabýval R. Psotta (2003). 
né prì výběru výzkumného souboru i při sběru dat pro obě videostudie totožné.

Naším původním záměrem bylo pracovat $s$ náhodně vybranými učiteli v České republice, randomizace při výběru učitelů však byla z technických důvodů neproveditelná. Náhodný výběr byl proto uplatněn při výběru základních škol. Výběr byl rovněž omezen regionálně, byly vybrány tři kraje, které byly pro pracovníky Centra pedagogického výzkumu PdF MU technicky nejdostupnější.

MŠMT ČR eviduje na území Jihomoravského, Olomouckého a Zlínského kraje celkem 984 základních škol (viz Seznam základních škol...). Zkušební výběry ukázaly, že při neváženém náhodném výběru by ve vzorku z demografických důvodů velmi silně převažovaly školy v malých sídlech ( 50 \% všech základních škol je situováno v obcích s méně než 1500 obyvateli), u kterých se dá předpokládat, že je navštěvuje méně žáků a že zde vyučuje méně učitelů, než na školách v sídlech s větším počtem obyvatel. $Z$ tohoto důvodu byl proveden výběr vážený dle velikosti sídla, ve kterém je škola situována.

Pro vážení výběru bylo 984 škol vybraného regionu (na území Jihomoravského, Olomouckého a Zlínského kraje) rozděleno do pěti kategorií (tab. 1).

\begin{tabular}{|l|c|c|c|}
\hline kategorie & $\begin{array}{l}\text { počet obyvatel sídla, } \\
\text { ve kterém se škola nachází }\end{array}$ & $\begin{array}{c}\text { škol v základním } \\
\text { souboru }\end{array}$ & v „losovacím koši“ \\
\hline 1. & $\mathrm{x} \leq 722$ & $\mathrm{n}=198$ & $1 \mathrm{x}$ \\
\hline 2. & $722<\mathrm{x}<1160$ & $\mathrm{n}=196$ & $2 \mathrm{x}$ \\
\hline 3. & $1161<\mathrm{x}<2530$ & $\mathrm{n}=197$ & $3 \mathrm{x}$ \\
\hline 4. & $2531<\mathrm{x}<25000$ & $\mathrm{n}=201$ & $4 \mathrm{x}$ \\
\hline 5. & $25001 \leq \mathrm{x}$ & $\mathrm{n}=192$ & $5 \mathrm{x}$ \\
\hline
\end{tabular}

Tab. 1: Základní školy vybraného regionu dle počtu obyvatel daného sídla a jejich vážení

S pomocí generátoru náhodných čísel (Statistica 7.1) byl proveden náhodný vážený výběr 45 základních škol. V takto vybraném souboru bylo 15 škol neúplných, málotřídních nebo zvláštních, a proto byly vyřazeny. Zbývající základní školy ( $\mathrm{n}=$ 30) byly osloveny, aby se zúčastnily projektu CPV videostudie tělesné výchovy (podrobněji viz Miková, Janík 2007a).

Tabulky 2 a 3 shrnují počty základních škol zapojených do projektu CPV videostudie tělesné výchovy podle kraje, resp. podle velikosti sídla, ve kterém je škola situována. 


\begin{tabular}{|l|c|}
\hline & $\begin{array}{c}\text { Počet škol zapojených } \\
\text { do projektu CPV videostudie Tv }\end{array}$ \\
\hline Jihomoravský kraj & 9 \\
\hline Zlínský kraj & 5 \\
\hline Olomoucký kraj & 5 \\
\hline
\end{tabular}

Tab. 2: Školy zapojené do projektu CPV videostudie Tv podle kraje

\begin{tabular}{|c|c|}
\hline & $\begin{array}{c}\text { Počet škol zapojených } \\
\text { do projektu CPV videostudie TV }\end{array}$ \\
\hline $\mathrm{x} \leq 722$ & 0 \\
\hline $722<\mathrm{x}<1160$ & 2 \\
\hline $1161<\mathrm{x}<2530$ & 4 \\
\hline $2531<\mathrm{x}<25000$ & 5 \\
\hline $25001 \leq \mathrm{x}$ & 8 \\
\hline
\end{tabular}

Tab. 3: Školy zapojené do projektu CPV videostudie Tv podle velikosti daného sídla

S řediteli vybraných škol byla vedena osobní jednání, která měla za cíl osvětlit cíle výzkumu a konkretizovat harmonogam pořizování videozáznamů. Přestože byl na každém $z$ těchto osobních jednání zdůrazněn záměr pořídit videozáznamy 4 vyučovacích jednotek tělesné výchovy $v$ 7. nebo 8 . ročníku u jednoho učitele, přesto se nepodařilo tomuto záměru z různých důvodů dostát (rozvrh neumožnil vhodnou koordinaci během natáčecího dne, více učitelů mezi sebe rozložilo natáčecí „zátěž", výuka byla neplánovaně zrušena, v tělesné výchově slučují šesté a sedmé ročníky, apod.). V CPV videostudii tělesné výchovy byly pořizeny videozáznamy 51 vyučovacích jednotek o délce 45 minut a 7 vyučovacích jednotek o délce 90 minut u celkem 20 učitelů.

Data byla sbírána v období únor až červen 2007. Celkem probíhalo natáčení ve 44 dnech. Tělesná výchova jako předmět vyučovaný na základních školách má svá specifika, která je třeba zohlednit při pořizování videozáznamů. Původně se měla zaznamenávat výuka tělesné výchovy pouze $v$ 7. a 8. ročníku. Vzhledem k nedostatku žáků, především na menších školách, často dochází ke spojování tělesné výchovy (6. ročník je spojován se 7. ročníkem, 8. ročník je spojován s 9. ročníkem). Dalším specifikem je dělení žáků na skupinu dívek a skupinu chlapců.

Časová dotace tělesné výchovy na 2. stupni základní školy činí dvě hodiny týdně, tj. 2 x 45 minut. Vzhledem k časovým možnostem učitelů a žáků probíhá tělesná výchova na některých školách pouze jednou týdně, a to v délce 90 minut. Při sběru dat v našem výzkumném vzorku jsme pořídili videozáznam sedmi vyučovacích jednotek, které trvaly 90 minut. Soubor dále obsahuje videozáznamy 51 vyučovacích jednotek v délce 45 minut (tab. 4).

Při výuce tělesné výchovy je využíván nejen prostor $v$ tělocvičnách, ale také na jiných sportovištích. Většina škol disponuje venkovními sportovními hřišti, v ojedinělých prípadech se setkáváme s tím, že prímo v areálu školy je plavecký bazén. 
Výuka tělesné výchovy, kterou jsme zaznamenávali na video, se většinou odehrávala $v$ tělocvičně, často také na sportovním hřišti a $v$ jednom prípadě $v$ plavecké hale. Pro $C P V$ videostudii byly vytvořeny standardizované postupy natáčení vyučovacích hodin (Janík, Miková 2006). Vzhledem k různosti prostředí, ve kterém se tělesná výchova může odehrávat, bylo nutné tyto postupy mírně modifikovat. Každá vyučovací jednotka tělesné výchovy byla zachycena dvěma videokamerami (obr. 1). První - učitelská kamera snímala učitele. Druhá - žákovská kamera snímala činnosti co možná největšího počtu žáků. Oproti dosavadním zvyklostem, kdy učitelskou kameru drží v rukou kameraman a žákovská kamera je upevněna na stativu, bylo při pořizování videozáznamů tělesné výchovy zapotřebí, aby i žákovskou kameru obsluhoval kameraman. Žákovská kamera byla upevněna i nadále na stativu, ale kameraman s ní podle potřeby pohyboval. Další novinkou bylo použití bezdrátového klopového mikrofonu pro učitele.

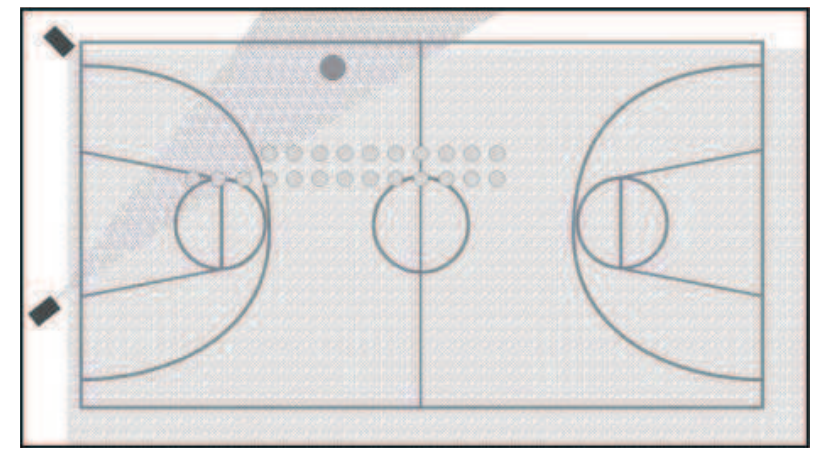

Obr. 1: Pozice kamer v tělocvičně

Jak ukazuje tabulka 4, v CPV videostudii tělesné výchovy participovalo 20 učitelů (n $=10$ žen +10 mužů) o průměrné délce praxe dvanáct a půl roku. Délka praxe se pohybovala od 2 do 44 let. Celkem 8 učitelů má praxi 2 až 5 let včetně; 5 učitelů má praxi 11-15 let. Výjimečný je prípad, kdy jeden učitel má praxi 44 let. Ve zkoumaném vzorku bylo 17 učitelů aprobovaných pro výuku tělesné výchovy, 2 z nich studují tělesnou výchovu a 1 z nich má vystudovanou tělesnou výchovu v rámci oboru Učitelství pro 1. stupeň základní školy.

\begin{tabular}{|c|c|c|c|c|c|c|c|}
\hline 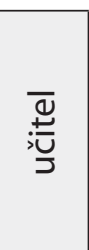 & 홍 & 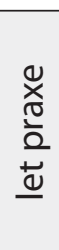 & $\begin{array}{l}\stackrel{\Xi}{0} \\
\tilde{0} \\
0 \\
\frac{0}{0} \\
\frac{0}{\sigma}\end{array}$ & 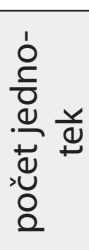 & 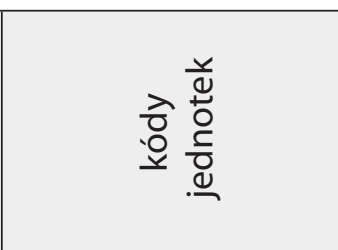 & 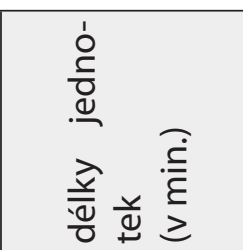 & $\begin{array}{l}\frac{\lambda}{0} \\
\frac{v}{2 n} \\
\frac{0}{2} \\
\frac{v}{\sqrt[N]{N}}\end{array}$ \\
\hline Tv_A & ž & 30 & $\mathrm{Tv}, \mathrm{Bv}, \mathrm{ORv}, \mathrm{Pc}$ & 4 & $\begin{array}{l}\text { Tv_A1,Tv_A2,Tv_A3, } \\
\text { Tv_A4 }\end{array}$ & $45+45+45+45$ & 720 \\
\hline Tv_B & ž & 8 & Z, Tv, Psy & 4 & $\begin{array}{l}\text { Tv_B1, Tv_B2, Tv_B3, } \\
\text { Tv_B4 }\end{array}$ & $45+45+45+45$ & 500 \\
\hline
\end{tabular}




\begin{tabular}{|c|c|c|c|c|c|c|c|}
\hline Tv_C & ž & 22 & Tv, Bv & 3 & Tv_C1,Tv_C2,Tv_C3 & $45+45+45$ & 160 \\
\hline Tv_D & ž & 13 & $\begin{array}{l}\text { 1. stupeň } \\
(+\mathrm{Hv})\end{array}$ & 4 & \begin{tabular}{|l} 
Tv_D1,Tv_D2, \\
Tv_D3,Tv_D4
\end{tabular} & $45+45+45+45$ & 140 \\
\hline Tv_E & $\mathrm{m}$ & 3 & Tv & 2 & Tv_E1,Tv_E2 & $90+90$ & 730 \\
\hline Tv_F & $\mathrm{m}$ & 19 & $\mathrm{M}, \mathrm{TV}$ & 3 & Tv_F1,Tv_F2,Tv_F3 & $45+45+45$ & 160 \\
\hline Tv_G & $m$ & 28 & $\mathrm{Tv}, \mathrm{Ze}$ & 2 & Tv_G1,Tv_G2 & $45+45$ & 210 \\
\hline Tv_H & $\mathrm{m}$ & 4 & Tv, Př & 3 & Tv_H1,Tv_H2,Tv_H3 & $45+45+45$ & 500 \\
\hline Tv_I & $m$ & 4 & $\mathrm{Tv}, \mathrm{Bi}$ & 2 & Tv_I1,Tv_12 & $90+90$ & 730 \\
\hline$T v_{-} J$ & ž & 13 & $\mathrm{Tv}, \mathrm{Bi}$ & 2 & Tv_J1,TV_J2 & $90+90$ & 590 \\
\hline Tv_K & ž & 3 & $\mathrm{Tv}$ & 3 & Tv_K1,Tv_K2,Tv_K3 & $45+45+45$ & 220 \\
\hline TV_L & ž & 9 & $\mathrm{Tv}, \mathrm{Ov}$ & 3 & Tv_L1,Tv_L2,Tv_L3 & $45+45+45$ & 400 \\
\hline Tv_M & ž & 2 & Tv & 4 & $\begin{array}{l}\text { Tv_M1,Tv_M2, } \\
\text { Tv_M3,Tv_M4 }\end{array}$ & $45+45+45+45$ & 450 \\
\hline Tv_N & ž & 12 & $\begin{array}{l}\text { Tv, Ped, Ped } \\
\text { psych }\end{array}$ & 2 & Tv_N1, Tv_N2 & $45+45$ & 650 \\
\hline Tv_O & $\mathrm{m}$ & 11 & $\mathrm{Tv}$ & 2 & Tv_O1,Tv_O2 & $45+45$ & 650 \\
\hline Tv_P & $\mathrm{m}$ & 5 & studující Tv & 4 & $\begin{array}{l}\text { Tv_P1, Tv_P2, Tv_P3, } \\
\text { Tv_P4 }\end{array}$ & $45+45+45+45$ & 200 \\
\hline Tv_Q & $\mathrm{m}$ & 44 & $\mathrm{Rj}, \mathrm{Ov}, \mathrm{Tv}$ & 2 & Tv_Q1,Tv_Q2 & $45+45$ & 270 \\
\hline Tv_R & ž & 3 & $\mathrm{Tv}, \mathrm{Bi}$ & 3 & Tv_R1,Tv_R2,Tv_R3 & $90+45+45$ & 450 \\
\hline Tv_S & $\mathrm{m}$ & 5 & $\begin{array}{c}\text { Př (studující } \\
\text { Tv) }\end{array}$ & 3 & Tv_S1,Tv_S2,Tv_S3 & $45+45+45$ & 490 \\
\hline$T v_{-} T$ & $\mathrm{~m}$ & 11 & $\mathrm{Tv}, \mathrm{Ch}$ & 3 & Tv_T1,Tv_T2,Tv_T3 & $45+45+45$ & 550 \\
\hline
\end{tabular}

Tab. 4: Učitelé zapojení do projektu CPV videostudie tělesné výchovy

V rámci $C P V$ videostudie tělesné výchovy probíhalo pořizování videozáznamů na 19 školách (tab. 2). Na jedné škole byly pořízeny videozáznamy výuky u dvou učitelů tělesné výchovy. Podle velikosti Ize školy rozdělit do tři skupin: škola s počtem žáků menším než 250 , škola s počtem žáků od 250 do 500 včetně, škola nad 500 žáků. Shodný počet vyučovacích jednotek byl zaznamenán ve školách s počtem žáků od 250 do 500 včetně a ve školách s počtem žáků větším než 500 . Ukázalo se, že na školách, které mají více než 500 žáků, jsou nejvíce využívány devadesátiminutové vyučovací jednotky. Celkem zde bylo zaznamenáno 11 vyučovacích jednotek $v$ délce 45 minut a 6 vyučovacích jednotek $v$ délce 90 minut. Na školách s počtem žáků od 250 do 500 včetně bylo zaznamenáno celkem 21 vyučovacích jednotek $v$ délce 45 minut a 1 vyučovací jednotka v délce 90 minut. Nejméně vyučovacích jednotek, ale ve srovnání s výše uvedenou kategorizací srovnatelný počet, bylo zaznamenáno ve školách s počtem žáků menším než 250 . Celkem zde bylo zaznamenáno 19 vyučovacích jednotek $v$ délce 45 minut. Nebyla zde pořízena žádná vyučovací jednotka trvající 90 minut. 


\subsection{Do jaké míry byly zaznamenané vyučovací jednotky autentické?}

V metodologických diskusích se často poukazuje na to, že vyučovací jednotky zaznamenávané na video nemusí být zcela autentické. Uvádí se, že takové hodiny jsou zkreslené směrem k sociální „žádoucnosti“ (učitel předvádí „ideální" hodinu), nebo že jsou „nepovedené" právě kvůli přítomnosti kamery (učitel je nervózní, žáci se „předváději"). Autentičnost zaznamenaných vyučovacích jednotek byla monitorována dotazníky, které byly učitelům distribuovány po skončení každé jednotky. Z odpovědí (tab. 5) je patrné, že více než $95 \%$ zaznamenaných vyučovacích jednotek učitelé označili jako typické nebo spiše typické, v $90 \%$ vyučovacích jednotek se žáci podle učitele chovali jako obvykle a v $98 \%$ vyučovacích jednotek se učitelé cítili velmi dobře nebo byli jen mírně nervózní. Domníváme se proto, že prítomnost kamery průběh výuky spíše nenarušila.

\begin{tabular}{lcc}
\hline & $\begin{array}{c}\text { Absolutní } \\
\text { četnost } \\
\mathrm{n}=58\end{array}$ & $\begin{array}{c}\text { Relativní } \\
\text { četnost }\end{array}$ \\
\hline Byla tato hodina typická ve srovnání s Vašimi obvyklými hodinami? & 44 & $75,9 \%$ \\
typická & 12 & $20,7 \%$ \\
spíše typická & 2 & $3,4 \%$ \\
spíše netypická & 0 & $0,0 \%$ \\
netypická & & \\
Jak se v této hodině chovali žáci? & 5 & $8,6 \%$ \\
lépe než obvykle & 52 & $89,7 \%$ \\
jako obvykle & 1 & $1,7 \%$ \\
hůřre než obvykle & 36 & \\
\hline Jak jste se v této hodině cítil(a)? & 21 & $62,1 \%$ \\
velmi dobře & 1 & $1,7 \%$ \\
mírně nervózní & 0 & $0,0 \%$ \\
nervózní & & \\
mimořádně nervózní & & \\
\hline
\end{tabular}

Tab. 5: Autentičnost vyučovacích jednotek pořízených v CPV videostudii tělesné výchovy

\section{Zamýšlené analýzy}

Analýzy realizované v CPV videostudii tělesnévýchovy se budou zaměřovat jednak na obecně didaktické aspekty výuky (zejména organizační formy a fáze výuky), což do jisté míry umožní srovnání mezi jednotlivými předměty CPV videostudie, jednak na oborově didaktické aspekty výuky tělesné výchovy (zejména didaktické rídicí styly, verbální projevy učitele, ztvárňování vzdělávacího obsahu). Analýzy oborově specifických aspektů výuky tělesné výchovy budou směřovat $k$ identifikaci rysů charakteristických pro tělesnou výchovu jako vyučovací předmět. 
V první etapě videostudie tělesné výchovy (2007-2008) se zaměříme na organizační formy výuky, fáze výuky a na didaktické rídicí styly, které se ve výuce tělesné výchovy uplatňují. Obecnější definiční vymezení těchto didaktických konceptů (např. organizační formy či fáze výuky), které je předloženo výše (Janík, Najvar v tomto čísle Orbis scholae), je třeba pro účely výzkumu výuky tělesné výchovy konkretizovat a specifikovat, a to zejména z pozice oborově didaktické. Uvedené koncepty považujeme za klíčové pro zkoumání procesů vyučování a učení odehrávajících se ve výuce. Pro účely výzkumu jsou tyto didaktické koncepty transformovány do kategoriálních systémů (viz dále). Průběžně se pracuje na zpřesňování jejích jednotlivých kategorií - vytvárí se „Manuál pro kódování vyučovacích jednotek tělesné výchovy".

\subsection{Organizační formy výuky}

Organizační formy výuky chápeme jako způsoby uspořádání aktivit/činností učitele a žáků ve výuce. Organizační formy výuky se týkají organizační stránky výuky. V tělesné výchově rozlišujeme nejčastěji tyto organizační formy: hromadnou, skupinovou, párovou a samostatnou práci. Tyto formy Ize označit jako sociálně-interakční, nebot' uspořádávají struktury vztahů a interakcí mezi učiteli a žáky ve výuce. Cílem analýzy bude identifikovat spektrum organizačních forem, v nichž se výuka tělesné výchovy odehrává. Budou se hledat odpovědi na otázky: V jakých organizačních formách se odehrává výuka tělesné výchovy a jaké je jejich časové zastoupení? Jaké organizační formy jsou ve výuce tělesné výchovy nejvice zastoupeny? Jaké je zastoupení organizačních forem $v$ jednotlivých fázích výuky? Předběžná podoba kategoriálního systému pro organizační formy výuky viz tab. 6.

\begin{tabular}{|l|l|}
\hline $\begin{array}{l}\text { FO TV 0: } \\
\text { žádná }\end{array}$ & $\begin{array}{l}\text { Týká se situací před výukou nebo po skončení výuky, případně } \\
\text { během přerušení výuky, nikoliv v průběhu výuky. }\end{array}$ \\
\hline $\begin{array}{l}\text { FO TV 1: } \\
\text { hromadná } \\
\text { práce (výklad/ } \\
\text { demonstrace/ } \\
\text { instrukce) }\end{array}$ & $\begin{array}{l}\text { V této formě výuky dominuje aktivita učitele, jedná se o jed- } \\
\text { nosměrnou komunikaci směrem od učitele k žákům. Cílem } \\
\text { je zprostředkovat žákům (nové) učivo, nebo zadat žáküm in- } \\
\text { strukce. Tato forma výuky bývá většinou doprovázena názor- } \\
\text { nou ukázkou. Příklad: Učitel stojí před žáky a svưj slovní projev } \\
\text { doplňuje názornou ukázkou. }\end{array}$ \\
\hline $\begin{array}{l}\text { FO TV 2: } \\
\text { hromadná } \\
\text { práce } \\
\text { (diktát/zápis } \\
\text { do sešitu) }\end{array}$ & $\begin{array}{l}\text { V této formě výuky dominuje aktivita učitele, jedná se o jed- } \\
\text { nosměrnou komunikaci, při níž učitel prezentuje text (diktuje, } \\
\text { píše na tabuli, promítá na zpětném projektoru fólie atd.) a žáci } \\
\text { jej opisují. Příklad: Učitel žákưm diktuje tělocvičné názvosloví, } \\
\text { nebo pravidla hry, nebo kompenzační cvičení, které mají prová- } \\
\text { dět doma, a žáci si zapisují. }\end{array}$ \\
\hline
\end{tabular}




\begin{tabular}{|c|c|}
\hline $\begin{array}{l}\text { FO TV 3: } \\
\text { hromadná } \\
\text { práce } \\
\text { (rozhovor se } \\
\text { trídou) }\end{array}$ & $\begin{array}{l}\text { V této formě výuky dominuje aktivita učitele, jedná se o obou- } \\
\text { směrnou komunikaci mezi učitelem a žáky. Učitel klade otáz- } \\
\text { ky a žáci na ně odpovídají. Také žák může klást otázku a učitel, } \\
\text { příp. jiní žáci na ni odpovídají. Cílem je zprostředkovat nové } \\
\text { učivo, príp. upřesnit již nabyté vědomosti, a to prostřednictvím } \\
\text { aktivizování žáků. Př́klad: Učitel diskutuje šzáky o způsobech ře- } \\
\text { šenípohybového úkolu. }\end{array}$ \\
\hline $\begin{array}{l}\text { FO TV 4: } \\
\text { samostatná/in- } \\
\text { dividuální práce }\end{array}$ & $\begin{array}{l}\text { V této formě výuky převládá aktivita žáků. Žáci samostatně, } \\
\text { individuálně plní zadaný úkol. Učitel komunikuje většinou jen } \\
\text { s jednotlivými žáky. V ojedinělých případech komunikuje s ce- } \\
\text { lou třídou. Příklad: Žáci si samostatně procvičují vysvětlenou čin- } \\
\text { nost. Platí i v př́ipadě, že žáci stojí v zástupu a čekají na možnost } \\
\text { (pokyn) zahájit činnost (např. kotoul, přeskok apod.). }\end{array}$ \\
\hline $\begin{array}{l}\text { 5: } \\
\text { á práce }\end{array}$ & $\begin{array}{l}\text { V této formě výuky převládá aktivita žáků. Dvojice žáků plní } \\
\text { zadaný úkol. Učitel většinou komunikuje s jednotlivými žáky } \\
\text { nebo s dvojić žáků. V ojedinělých př́padech komunikuje s ce- } \\
\text { lou třídou. Žáci ve dvojici spolu většinou komunikují, příp. si } \\
\text { dávají jedno či víceslovné pokyny, které má ten druhý ve dvo- } \\
\text { jici splnit. Př́klad: Žáci procvičují zadanou činnost ve dvojicích } \\
\text { (týká se např. míčových her - odbíjení, přihrávky apod.) }\end{array}$ \\
\hline $\begin{array}{l}\text { FO TV 6: } \\
\text { skupinová } \\
\text { práce }\end{array}$ & $\begin{array}{l}\text { V této formě výuky převládá aktivita žáků. Žáci plní zadané } \\
\text { úkoly ve skupině, která má tři a více žáků (Může se jednat také } \\
\text { o družstvo - skupina se stanoveným počtem hráčủ, která může } \\
\text { mít trvalejší charakter). Charakter zadaného úkolu mǔže být } \\
\text { různý. Bud' žáci společně ve stejnou dobu pracují na jednom } \\
\text { úkolu, nebo jednotliví žáci ve skupině plní úkol postupně. Uči- } \\
\text { tel většinou komunikuje s jednotlivými žáky nebo se skupinou } \\
\text { žáků. V ojedinělých případech komunikuje s celou tř́dou. Cí- } \\
\text { lem by měla být spolupráce žáků, při které dochází k vzájemné } \\
\text { interakci a komunikaci mezi žáky ve skupině. Příklad: Žáci pro- } \\
\text { cvičují zadanou činnost ve skupinách o třech a více žácích. Typic- } \\
\text { ké je cvičení skupin na stanovištích. }\end{array}$ \\
\hline $\begin{array}{l}\text { FO TV 7: } \\
\text { více forem sou- } \\
\text { časně }\end{array}$ & $\begin{array}{l}\text { Ve stejnou dobu (časově paralelně) probíhá několik forem vý- } \\
\text { uky, které mají pro výuku stejnou důležitost (jsou rovnocen- } \\
\text { né). Příklad: při větším počtu žáků učitel rozděli žáky na poloviny } \\
\text { a každá se věnuje jiné činnosti (napr. polovina žáků pracuje sa- } \\
\text { mostatně - skáče přes švihadlo; druhá polovina žáků pracuje ve } \\
\text { skupinách na stanovištích). }\end{array}$ \\
\hline $\begin{array}{l}\text { FO TV 8: } \\
\text { přechod }\end{array}$ & $\begin{array}{l}\text { Jedná se o předěl výuky, kdy skončila jedna část výuky a násle- } \\
\text { duje příprava na další část výuky. Příklad: Žáci připravují nářadi } \\
\text { a náčiní pro cvičení na stanovištích, nebo na povel učitele měni } \\
\text { stanoviště. }\end{array}$ \\
\hline
\end{tabular}




\begin{tabular}{|l|l|}
\hline $\begin{array}{l}\text { FO TV 9: } \\
\text { ostatní }\end{array}$ & $\begin{array}{l}\text { Týká se situací, které nelze jednoznačně přiřadit k žádné z výše } \\
\text { uvedených forem. }\end{array}$ \\
\hline
\end{tabular}

Tab. 6: Organizační formy výuky - obsahové vymezení kategorií

\subsection{Fáze výuky}

Fáze výuky chápeme jako různě dlouhé úseky výuky, které se vztahují k práci s učivem. Fáze postihují skutečnost, že učivo se v průběhu výuky objevuje $v$ různé míře své rozpracovanosti - od zprostředkování nového učiva, přes upevňování, aplikaci, opakování až po diagnostikování jeho osvojení (zkoušení). Fáze se vztahují k procesuální stránce výuky. $V$ tělesné výchově obvykle rozlišujeme tři fáze ${ }^{22}$ výuky: 1. úvodní (organizační část, rušná/zahřívací část, průpravná část), 2. hlavní (např. nácvik nových dovedností), 3. závěrečnou (kompenzační cvičení, zhodnocení). Toto členění je však schematické a neumožňuje hlouběji proniknout k podstatě procesů vyučování a učení v tělesné výchově. Proto je námi narvžený kategoriální systém (tab. 7) více elaborovaný. Cílem analýzy bude identifikovat spektrum fází, v nichž se výuka tělesné výchovy odehrává. Budou se hledat odpovědi na otázky: V jakých fázích se odehrává výuka tělesné výchovy a jaké je jejich časové zastoupení? Jaké fáze jsou ve výuce tělesné výchovynejvíce zastoupeny? Předběžná podoba kategoriálního systému pro fáze výuky viz tab. 7.

\begin{tabular}{|l|l|}
\hline $\begin{array}{l}\text { FA TV 0: } \\
\text { žádná }\end{array}$ & $\begin{array}{l}\text { Týká se situací před výukou nebo po skončení výuky, případně bě- } \\
\text { hem přerušení výuky, nikoliv v průběhu výuky. }\end{array}$ \\
\hline $\begin{array}{l}\text { FA TV 1: } \\
\text { opaková- } \\
\text { ní učiva }\end{array}$ & $\begin{array}{l}\text { Zahrnuje fáze výuky, ve kterých se pracuje s učivem probraným } \\
\text { v predchozích hodinách. Cílem je vyvolat již naučené do paměti. Pří- } \\
\text { klad: Učitel se tř́dou opakuje již probrané učivo (z predchozích hodin). }\end{array}$ \\
\hline $\begin{array}{l}\text { FA TV 2: } \\
\text { úvod ho- } \\
\text { diny }\end{array}$ & $\begin{array}{l}\text { Zahrnuje fáze výuky, v nichž je aktivní převážně učitel, který seznamu- } \\
\text { je žáky s tématem, cílem a průběhem výuky, př́padně žáky motivuje. } \\
\text { Obvykle je zde zahrnut také nástup a hlášení, které podává zvolený } \\
\text { žák. Příklad: Učitel nechá žáky nastoupit, seznámíje s průběhem hodiny, } \\
\text { s cíli a způsoby výuky. }\end{array}$ \\
\hline $\begin{array}{l}\text { FA TV 3: } \\
\text { zprostřed- } \\
\text { kování } \\
\text { nového } \\
\text { učiva }\end{array}$ & $\begin{array}{l}\text { Zahrnuje fáze výuky, v nichž učitel seznamuje žáky s novým učivem. } \\
\text { vedností, ale také vědomostí. Zprostředkování se zpravidla uskuteč- } \\
\text { ňuje verbálně a je doprovázeno názornou ukázkou. Přiklad: Učitel vy- } \\
\text { světluje nové učivo, slovní projev často doplňuje názornou ukázkou. }\end{array}$ \\
\hline $\begin{array}{l}\text { FA TV 4: } \\
\text { procvi- } \\
\text { čování/ } \\
\text { upevňo- } \\
\text { vání učiva }\end{array}$ & $\begin{array}{l}\text { Zahrnuje činnosti žáků, při nichž dochází k automatizaci dovedností } \\
\text { a fixaci vědomostí (probraného učiva). Žáci většinou na základě slov- } \\
\text { ní nebo písemné instruktáže plní zadané úkoly. Príklad: Žáci procvi- } \\
\text { čují (samostatně/ve dvojicích/ve skupinách/hromadně) právě probrané } \\
\text { učivo. }\end{array}$ \\
\hline
\end{tabular}

22 Namísto pojmu fáze výuky se v didaktice tělesné výchovy častěji používá pojem část výuky (srov. Vilímová 2002, s. 78-80). 


\begin{tabular}{|c|c|}
\hline $\begin{array}{l}\text { FA TV 5: } \\
\text { aplikace/ } \\
\text { prohlu- } \\
\text { bová-ní } \\
\text { učiva }\end{array}$ & $\begin{array}{l}\text { Zahrnuje fáze výuky, ve kterých se zprostředkované a procvičené } \\
\text { učivo uplatňuje v nových situacích. Aplikace se vztahuje k přenosu } \\
\text { probraného učiva na řešení problémových úloh. O prohlubování ho- } \\
\text { voříme, pokud se ve výuce objeví učivo, které je nad rámec základní- } \\
\text { ho učiva. Př́klad: Žáci aplikují naučené dovednosti ve hře/ve složitější } \\
\text { pohybové sestavě. }\end{array}$ \\
\hline $\begin{array}{l}\text { FA TV 6: } \\
\text { shrnutí } \\
\text { učiva }\end{array}$ & $\begin{array}{l}\text { Zahrnuje fáze výuky, při nichž dochází ke strukturování a organizo- } \\
\text { vání obsahu učiva, které bylo ve výuce zprostředkováno. Tato fáze } \\
\text { se většinou realizuje formou rozhovoru mezi učitelem a žáky. Př́iklad: } \\
\text { Učitel (nebo žák/žáci) zpravidla na konci hodiny v několika větách shrne, } \\
\text { co se v hodině učilo. }\end{array}$ \\
\hline $\begin{array}{l}\text { FA TV 7: } \\
\text { rekapitu- } \\
\text { lace }\end{array}$ & $\begin{array}{l}\text { Zahrnuje fáze výuky, v nichž se učitel spolu s žáky zabývá podporou } \\
\text { učebního procesu žáků. Zaměřuje se zejména na postupy či meto- } \\
\text { dy řešení úloh a problémů. Charakteristická je pro tuto fázi explicitní } \\
\text { zpětná vazba zaměřená na proces učení žáků a na jeho metakogni- } \\
\text { tivní podporu. Př́klad: Učitel (nebo žák/žáci) zpravidla na konci hodiny } \\
\text { v několika větách rekapituluje, jakým způsobem a v jakém sledu učení } \\
\text { probíhalo. }\end{array}$ \\
\hline \begin{tabular}{|l|} 
FA TV 8: \\
zkoušení/ \\
prověrka/ \\
kontrola \\
domácích \\
úkolů \\
\end{tabular} & $\begin{array}{l}\text { Zahrnuje fáze výuky, v nichž učitel zjištuje dovednosti a vědomosti } \\
\text { žáků, a to většinou na základě plnění praktických úkolü. Příklad:Učitel } \\
\text { testuje (boduje/známkuje/hodnotí) dovednosti žáků. }\end{array}$ \\
\hline $\begin{array}{l}\text { FA TV 9: } \\
\text { ostatní }\end{array}$ & $\begin{array}{l}\text { Týká se situací, které není možné přiřadit k žádné z výše uvedeným } \\
\text { fází výuky. }\end{array}$ \\
\hline
\end{tabular}

Tab. 7: Fáze výuky - obsahové vymezení kategorií

\subsection{Didaktické řídicí styly}

Didaktické řídicí styly označují určitý aspekt učitelova jednání, který určuje aktivity žáků ve výuce (Mosston, Ashworth 2002; Dobrý 2007). Teorie spektra didaktických rrídicích stylů vychází z předpokladu, že vyučování je racionální, cílevědomou a plánovanou činností založenou na učitelově rozhodování (se) pro určitou alternativu jednání ve výuce. $V$ této teorii je navíc zohledněn postupný přesun těžiště rozhodování z učitele na žáky. Cílem analýzy bude identifikovat širíi spektra didaktických ř́dicích stylů uplatňovaných ve výuce tělesné výchovy. Budou se hledat odpovědi na otázky Jak širokéje spektrum didaktických rídicích stylů uplatňovaných ve výuce? Které didaktické ř́dicí styly se uplatňují nejčastěji? Předběžná podoba kategoriálního systému pro didaktické rídící styly viz tab. 8. Obsahové vymezení didaktických řídicích stylů je převzato z práce Dobrý (2007). 


\begin{tabular}{|c|c|c|c|c|}
\hline \multirow[b]{3}{*}{$\begin{array}{l}\text { Didaktické rídicí styly } \\
\text { (obsahové vymezení) }\end{array}$} & \multicolumn{4}{|c|}{ Příklady uplatnění v různých organizačních formách, v různém učivu } \\
\hline & Forma: hromadná & Forma: skupinová & Forma: párová & Forma: samostatná \\
\hline & Učivo: skok přes švihadlo & Učivo: stoj na rukou & $\begin{array}{l}\text { Učivo: přihrávka obouruč tr- } \\
\text { čením }\end{array}$ & Učivo: kompenzační cvičení \\
\hline \multicolumn{5}{|l|}{$\begin{array}{l}\text { DS TV 0: } \\
\text { žádný } \\
\text { Týká se sekvencí před výukou, po skončení } \\
\text { výuky, během přerušení výuky, nikoliv v prü- } \\
\text { běhu výuky. }\end{array}$} \\
\hline $\begin{array}{l}\text { DS TV 1: } \\
\text { příkazový } \\
\text { Veškerá rozhodnutí dělá učitel sám, žák } \\
\text { reprodukuje podle modelu předloženého } \\
\text { učitelem. Mezi učitelovým podnětem a žá- } \\
\text { kovou odpovědí je prímý a bezprostřední } \\
\text { vztah. Př́ikazový signál je někdy přenesen na } \\
\text { hudbu, píštalku nebo rytmické tleskání. }\end{array}$ & $\begin{array}{l}\text { Žáci jsou v určeném tvaru (napr. } \\
\text { na značkách), všichni nacviču- } \\
\text { jí/procvičují shodný skok přes } \\
\text { švihadlo. Učitel udává rytmus } \\
\text { např. tleskáním, př́padně po- } \\
\text { mocí rytmické hudební skladby. } \\
\text { V príipadě korektivního zásahu } \\
\text { nebo hodnocení jednotlivce je } \\
\text { cvičení všech žákủ přerušeno. }\end{array}$ & $\begin{array}{l}\text { Žáci jsou ve skupinách, každá } \\
\text { skupina má určeno místo pro } \\
\text { cvičení (např. žíněnku). Na po- } \\
\text { vel učitele jeden žák ze skupiny } \\
\text { provádístoj na rukou, další žáci } \\
\text { poskytují dopomoc a záchranu. } \\
\text { Zahájení i ukončení každého } \\
\text { cviku se děje na povel učitele. } \\
V \text { prípadě korektivního zásahu } \\
\text { nebo hodnocení jednotlivce je } \\
\text { cvičení všech žákŭ přerušeno. } \\
\end{array}$ & $\begin{array}{l}\text { Žáci jsou ve dvojicích proti sobě } \\
\text { a přihrávají si určeným způso- } \\
\text { bem. Přihrávku však smějí pro- } \\
\text { vést jen na signál učitele, který } \\
\text { tímto pokynem sjednocuje ryt- } \\
\text { mus a frekvenci přihrávek. V př́- } \\
\text { padě korektivního zásahu nebo } \\
\text { hodnocení źáka je cvičení všech } \\
\text { přerušeno. }\end{array}$ & $\begin{array}{l}\text { Každý žák má zadán jiný kom- } \\
\text { penzační cvik. Učitel pomocí } \\
\text { signálů nebo rytmické hudby } \\
\text { udává rytmus cvičení. V př́ípa- } \\
\text { dě korektivního zásahu nebo } \\
\text { hodnocenížáka je cvičení všech } \\
\text { přerušeno. }\end{array}$ \\
\hline $\begin{array}{l}\text { DS TV 2: } \\
\text { úkolový } \\
\text { Na žáka se přesunuje rozhodování o volbě } \\
\text { postavení, prostoru, zahájení a zakončení } \\
\text { činnosti, individuálního tempa a rytmu a in- } \\
\text { tervalu mezi činností. Žáci mohou klást otáz- } \\
\text { ky, směřujíć k odstranění jejich případných } \\
\text { nejistot. Učiteli se nabídnou nové možnosti } \\
\text { komunikace se žáky a různé formy předání } \\
\text { úkolư žákủm. Obtížnost zadaného úkolu je } \\
\text { pro všechny žáky relativně shodná. }\end{array}$ & $\begin{array}{l}\text { Žáci zaujmou takové postave- } \\
\text { ní, aby měli na cvičení dostatek } \\
\text { místa. Všichni nacvičují/procvi- } \\
\text { čují shodný skok přes švihadlo, } \\
\text { ale ve vlastním tempu a rytmu. } \\
\text { Učitel obchází jednotlivé žáky } \\
\text { a individuálně je koriguje nebo } \\
\text { hodnotí. }\end{array}$ & $\begin{array}{l}\text { Žáci jsou ve skupinách, každá } \\
\text { skupina má přiděleno místo } \\
\text { pro cvičení (např. žíněnku). Žáci } \\
\text { mají předem určené role (cvičící, } \\
\text { nebo provádějícízáchranu a do- } \\
\text { pomoc), v nichž se samostatně } \\
\text { střídají. Učitel obchází jednotli- } \\
\text { vé skupiny a výkon jednotlivců } \\
\text { koriguje nebo hodnotí. }\end{array}$ & $\begin{array}{l}\text { Žáci jsou ve dvojicích proti sobě } \\
\text { a prihrávají si určeným zpü- } \\
\text { sobem, ale vlastním tempem } \\
\text { a intenzitou. Učitel obchází } \\
\text { jednotlivé žáky a individuálněje } \\
\text { opravuje a hodnotí. }\end{array}$ & $\begin{array}{l}\text { Každý žák má zadán jiný kom- } \\
\text { penzační cvik, který provádí } \\
\text { vlastním tempem. Učitel žáky } \\
\text { obchází a individuálně je kori- } \\
\text { guje nebo hodnotí. }\end{array}$ \\
\hline
\end{tabular}




\begin{tabular}{|c|c|c|c|c|}
\hline $\begin{array}{l}\text { DS TV 3: } \\
\text { se vzájemným hodnocením } \\
\text { Na žáka se přesunují rozhodnutí, která vyús- } \\
\text { tují do zpětných informacía korekcí poskyto- } \\
\text { vaných spolužákovi. Trí́da se rozdělí do párů } \\
\text { nebo skupin a každému jednotlivci v páru } \\
\text { je přidělena specifická role: jeden žák vyko- } \\
\text { nává činnost, druhý žák pozoruje, hodnotí, } \\
\text { opravuje, pomáhá. Objevují se nové poža- } \\
\text { davky na komunikaci učitele se žáky: učitel } \\
\text { se pohybuje mezi žáky, pozoruje výkon jak } \\
\text { cvičícího, tak pozorujícího a se svými prípo- } \\
\text { mínkami se obrací zejména na pozorovatele. } \\
\text { Žáci se sami delegují do funkcí. }\end{array}$ & $\begin{array}{l}\text { Žáci zaujmou takové postave- } \\
\text { ní, aby měli na cvičení dostatek } \\
\text { místa. Všichni nacvičují/procvi- } \\
\text { čuji shodný skok přes švihadlo, } \\
\text { ale ve vlastním tempu a rytmu. } \\
\text { Při cvičení si všímají i ostatních } \\
\text { spolužáků a po ukončení cviče- } \\
\text { ní na pokyn učitele hodnotí, kdo } \\
\text { prováděl cvičení nejlépe a jaké } \\
\text { chyby byly u spolužákü pozo- } \\
\text { rovány. }\end{array}$ & $\begin{array}{l}\text { Žáci jsou ve skupinách, každá } \\
\text { skupina má príděleno misto pro } \\
\text { cvičení(např.žíněnku). Žáci mají } \\
\text { předem určené role (cvičicí, pro- } \\
\text { vádějicí záchranu a dopomoc, } \\
\text { anebo hodnotící), v nichž se sa- } \\
\text { mostatně střídají. Učitel obchá- } \\
\text { zí jednotlivé skupiny a diskutuje } \\
\text { predevším s hodnotitelem. }\end{array}$ & $\begin{array}{l}\text { Žáci jsou ve dvojicích proti sobě } \\
\text { a přihrávají si určeným způso- } \\
\text { bem. Učitel obchází jednotlivé } \\
\text { žáky a ptá se jich, jak hodnotí } \\
\text { výkon a provedení přihrávky } \\
\text { svého spoluhráče. }\end{array}$ & $\begin{array}{l}\text { Každý žák má zadán jiný kom- } \\
\text { penzační cvik, který provádí } \\
\text { vlastním tempem a intenzitou. } \\
\text { Při cvičení si žáci všímají i ostat- } \\
\text { ních spolužáků a po ukončení } \\
\text { cvičení na pokyn učitele hodno- } \\
\text { tí, kdo prováděl cvičení nejlépe } \\
\text { a jaké chyby byly u spolužáků } \\
\text { pozorovány. }\end{array}$ \\
\hline $\begin{array}{l}\text { DS TV 4: } \\
\text { se sebehodnocením } \\
\text { Na žáka se přesunují rozhodnutí, která vyús- } \\
\text { tuují do sebehodnocení. Žák vykonává úlohy } \\
\text { samostatně, učí se používat daná kritéria } \\
\text { a sám sebe hodnotit. }\end{array}$ & $\begin{array}{l}\text { Žáci zaujmou takové postave- } \\
\text { ní, aby měli na cvičení dostatek } \\
\text { místa. Všichni nacvičuji/procvi- } \\
\text { čují shodný skok přes švihadlo, } \\
\text { ale ve vlastním tempu a rytmu. } \\
\text { Učitel obchází jednotlivé žáky } \\
\text { a věnuje se jejich sebehodno- } \\
\text { cení. }\end{array}$ & $\begin{array}{l}\text { Žáci jsou ve skupinách, každá } \\
\text { skupina má priiděleno místo } \\
\text { pro cvičení (např̌ž́íněnku). Žáci } \\
\text { mají předem určené role (cvičí- } \\
\text { cí, nebo provádějící záchranu } \\
\text { a dopomoc), v nichž se samo- } \\
\text { statně střídají. Učitel obchází } \\
\text { jednotlivé skupiny a zajímá se } \\
\text { o sebehodnocení žáka, který } \\
\text { docvičil. }\end{array}$ & $\begin{array}{l}\text { Žáci jsou ve dvojicích proti sobě } \\
\text { a prìhrávají si určeným způso- } \\
\text { bem. Učitel obchází jednotlivé } \\
\text { žáky a ptá se jich, jak hodnotí } \\
\text { svůj výkon a provedení přihráv- } \\
\text { ky. }\end{array}$ & $\begin{array}{l}\text { Každý žák má zadán jiný kon- } \\
\text { diční cvik, který provádí vlast- } \\
\text { ním tempem a intenzitou. Učitel } \\
\text { žáky obchází a zajímá se o jejich } \\
\text { pocity a sebehodnocení. }\end{array}$ \\
\hline $\begin{array}{l}\text { DS TV 5: } \\
\text { s nabídkou } \\
\text { Na žáka se přesunují rozhodnutí o obtížnosti } \\
\text { pohybového úkolu, žák si např. volí různou } \\
\text { výšku přkonávaného nářadí (např. šikmo } \\
\text { zavěšeného lana). }\end{array}$ & $\begin{array}{l}\text { Žáci zaujmou takové postave- } \\
\text { ní, aby měli na cvičení dostatek } \\
\text { místa. Učitel nabídne žákům } \\
\text { skoky s různou obtižností. Kaž- } \\
\text { dýžák si individuálnězvolískok, } \\
\text { který bude nacvičovat/procvi- } \\
\text { čovat. Učitel žáky individuálně } \\
\text { koriguje nebo hodnotí. }\end{array}$ & $\begin{array}{l}\text { Žáci jsou ve skupinách, každá } \\
\text { skupina má priiděleno místo } \\
\text { pro cvičení (napřr. žíněnku). Žáci } \\
\text { mají předem určené role (cvičící, } \\
\text { nebo provádějicízáchranu a do- } \\
\text { pomoc), v nichž se samostatně } \\
\text { stř́dají. Cvičící si volí, zda hodlá } \\
\text { provést stoj na rukou s dopomo- } \\
\text { cí, nebo bez dopomoci. Učitel } \\
\text { obchází jednotlivé skupiny a vý- } \\
\text { kon jednotlivcú koriguje nebo } \\
\text { hodnotí. }\end{array}$ & $\begin{array}{l}\text { Žáci jsou ve dvojicích proti sobě } \\
\text { a prihhrávají si zpưsobem, kte- } \\
\text { rý si vyberou z nabídky učitele } \\
\text { (priihrávka na krátkou či na větší } \\
\text { vzdálenost, o zem apod.). Učitel } \\
\text { obchází jednotlivé żáky a jejich } \\
\text { výkon hodnotí. }\end{array}$ & $\begin{array}{l}\text { Každý žák má zadán jiný kom- } \\
\text { penzační cvik, ale volí si jeho } \\
\text { obtižnost (počet opakování, } \\
\text { rozsah pohybu apod.). Učitel } \\
\text { žáky obchází a individuálně je } \\
\text { koriguje nebo hodnotí. }\end{array}$ \\
\hline
\end{tabular}




\begin{tabular}{|c|c|c|c|c|}
\hline $\begin{array}{l}\text { DS TV 6: } \\
\text { s řízeným objevováním } \\
\text { V tomto stylu se překračuje tzv. kognitivní } \\
\text { práh, který představuje hranici mezi repro- } \\
\text { dukcí známého a předem daného (styly } 1, \\
2,3,4,5 \text { ) a objevováním a produkcí nezná- } \\
\text { mého. Učivo předkládá učitel žákům v otáz- } \\
\text { kách, které je vedou ke konečnému rešení } \\
\text { - objevu. }\end{array}$ & $\begin{array}{l}\text { Žáci zaujmou takové postave- } \\
\text { ní, aby měli na cvičení dostatek } \\
\text { mista. Učitel pomocí otázek ak- } \\
\text { tivizuje žáky a vede je ke správ- } \\
\text { nému řešení nového druhu sko- } \\
\text { ku, např. snožmo vzad. Otázky: } \\
\text { Jaké bude základní postavení? } \\
\text { Jakým zpưsobem budete držet } \\
\text { švihadlo? Bude švihadlo před } \\
\text { tělem, nebo za tělem? Atd. }\end{array}$ & $\begin{array}{l}\text { Žáci jsou ve skupinách, každá } \\
\text { skupina má přiděleno místo pro } \\
\text { cvičení (např. žíněnku). Žáci ne- } \\
\text { mají předem určené role, jejich } \\
\text { úkolem je s pomocí návodných } \\
\text { otázek nalézt nejúčelnější zpü- } \\
\text { sob provedení stoje na rukou } \\
\text { i způsob dopomoci a záchrany. } \\
\text { Př́klad otázek: Z jakého po- } \\
\text { stavení budete zahajovat stoj } \\
\text { na rukou? Kde budou stát žáci } \\
\text { poskytujicí dopomoc? Kdo a jak } \\
\text { bude poskytovat záchranu? }\end{array}$ & $\begin{array}{l}\text { Žáci jsou ve dvojicích proti sobě, } \\
\text { učitel navozuje řešení problému } \\
\text { otázkami, např.: Jak se drží míč } \\
\text { v košíkové? V jaké poloze jsou } \\
\text { prsty? Jakým způsobem se míč } \\
\text { přihraje? Vjaképoloze jsou paže } \\
\text { čekající na príjem míče? }\end{array}$ & $\begin{array}{l}\text { Žáci nemají zadané cviky, ale } \\
\text { s pomocí návodných otázek } \\
\text { učitele hledají provedení cviku } \\
\text { směrujujíí k protahování nebo } \\
\text { zpevňování určené svalové sku- } \\
\text { piny. Cíl každého individuálního } \\
\text { cvičení může být předem vyme- } \\
\text { zen napřn na úkolových kartách. }\end{array}$ \\
\hline $\begin{array}{l}\text { DS TV 7: } \\
\text { se samostatným objevováním } \\
\text { Samostatné objevování představuje rešení } \\
\text { problému. Naskýtá se žákům možnost hle- } \\
\text { dat v pohybové činnosti rưzné alternativy } \\
\text { a vybírat z nich tu nejlepší. Při řešení pro- } \\
\text { blémů, tj. při samostatném objevování, Ize } \\
\text { objevovat fakty, vztahy, preference, limity, } \\
\text { pojmy, obměny. Prohlubuje se individuální } \\
\text { charakter učení. }\end{array}$ & \begin{tabular}{|l|} 
Učitel aktivizuje žáky tím, že \\
maji sami objevit nový druh \\
skoku pres švihadlo. Hodnotí in- \\
dividuálně i hromadně výsledek \\
samostatného objevování.
\end{tabular} & $\begin{array}{l}\text { Žáci jsou ve skupinách, žádná } \\
\text { skupina nemá přiděleno místo } \\
\text { pro cvičení, ani předem určené } \\
\text { role. Úkolem je samostatně při- } \\
\text { pravit stanoviště a nalézt nejú- } \\
\text { čelnější způsob provedení stoje } \\
\text { na rukou i způsob dopomoci } \\
\text { a záchrany. Učitel hodnotí práci } \\
\text { každéskupiny. }\end{array}$ & $\begin{array}{l}\text { Žáci jsou ve dvojicích proti sobě } \\
\text { a sami hledají nejúčelnější pro- } \\
\text { vedení príhrávky. Učitel hodnotí } \\
\text { individuálně i hromadně výsle- } \\
\text { dek samostatného objevování. }\end{array}$ & $\begin{array}{l}\text { Žáci nemají zadané cviky, ale } \\
\text { úkoly směrujicí k protahování } \\
\text { nebo zpevňování určité svalové } \\
\text { skupiny. Cíl každého individuál- } \\
\text { ního cvičení mǔže být předem } \\
\text { vymezen např. na úkolových } \\
\text { kartách. Žáci samostatně hle- } \\
\text { dají nejvhodnější zpưsob řešení. }\end{array}$ \\
\hline $\begin{array}{l}\text { DS TV 8: } \\
\text { s autonomním rozhodováním žáka } \\
\text { o učivu } \\
\text { Po náležitém objasnění učitelem určuje žák } \\
\text { samostatně otázku nebo vymezuje problém, } \\
\text { který chce řešit. Realizací vlastní volby vzniká } \\
\text { individuální program, jehož autorem je žák } \\
\text { sám. Předpokladem účasti v tomto stylu je } \\
\text { žákova připravenost na základě zkušeností } \\
\text { ze stylu 1-7. }\end{array}$ & $\begin{array}{l}\text { Každý žák se samostatně roz- } \\
\text { hodne, zda se bude věnovat ná- } \\
\text { cviku skoku přes švihadlo, nebo } \\
\text { procvičovat/opakovat zcela } \\
\text { jinou pohybovou dovednost } \\
\text { (např. hod na koš). }\end{array}$ & $\begin{array}{l}\text { Každý žák se samostatně roz- } \\
\text { hodne, zda se bude věnovat ná- } \\
\text { cviku stoje na rukou, anebo pro- } \\
\text { cvičovat/opakovat zcela jinou } \\
\text { pohybovou dovednost (např. } \\
\text { skok přes švihadlo). }\end{array}$ & $\begin{array}{l}\text { Každý žák se samostatně roz- } \\
\text { hodne, zda se bude věnovat } \\
\text { nácviku prihrávky, nebo pro- } \\
\text { cvičovat/opakovat zcela jinou } \\
\text { pohybovou dovednost (např. } \\
\text { dribling, hod na koš apod.). }\end{array}$ & $\begin{array}{l}\text { Každý žák si sám volí kompen- } \\
\text { zační cvik s ohledem na svou } \\
\text { úroveň zdatnosti nebo podle } \\
\text { aktuální kondice. }\end{array}$ \\
\hline
\end{tabular}




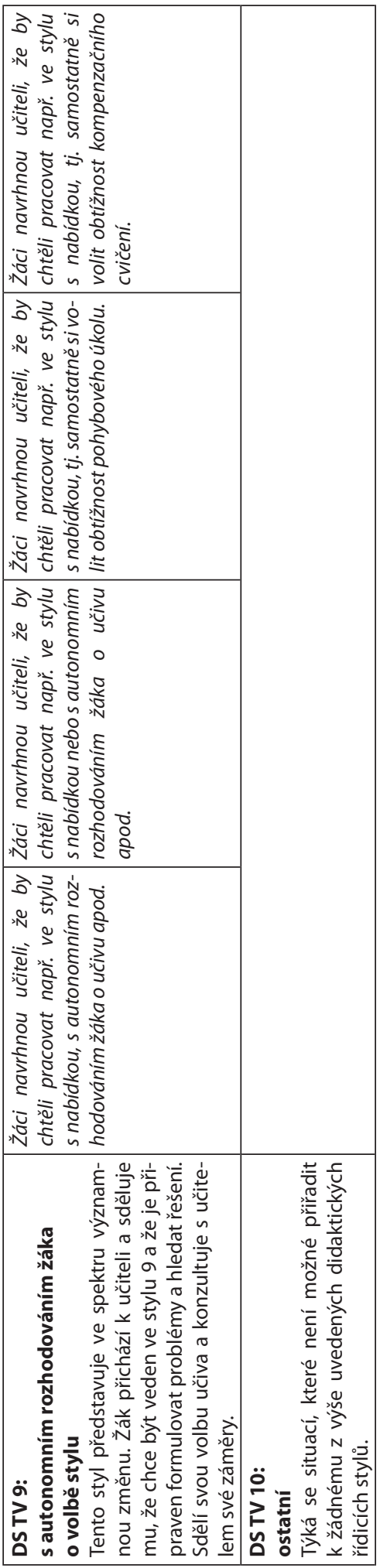

\subsection{Verbální projevy učitele}

Cílem bude podat rozbor verbálních projevů učitelů tělesné výchovy se zaměřením na jejich obsahovou a formální stránku. Budou se hledat odpovědi na otázky: Jaké didaktické funkce plní učitelovy verbální projevy? Jaká pravidla komunikace se ve výuce tělesné výchovy uplatňují? a další. Výsledky těchto analýz budou vztaženy $\mathrm{k}$ výsledkům kódování organizačních forem výuky, fází výuky a didaktických řídicích stylů, což umožní zjistit, jaké verbální projevy se jeví jako typické v jednotlivých organizačních formách, fázích a stylech řízení výuky.

\subsection{Obsahová stránka vyučování a učení}

Cíl této analýzy bude spočívat ve sledování obsahové stránky vyučování a učení ve výuce tělesné výchovy. Budou se hledat odpovědi na otázky: Jaké vzdělávací obsahy (učivo) jsou ve výuce tělesné výchovy zprostředkovávány a jakým způsobem? Jaké formy reprezentace vzdělávacího obsahu se prìtom uplatňují? Do jaké míry nabízí výuka tělesné výchovy príležitosti pro učení různého druhu (napr. motorické, sociální, kognitivní)? a další. Předpokládá se, že $v$ rámci těchto analýz bude také tematizován problém vztahu mezi projektovaným a realizovaným kurikulem (Mužík, Janík 2007).

\section{Závěr}

$\checkmark$ příspěvku byl představen projekt $C P V$ videostudie tělesné výchovy $v$ širším kontextu projektů CPV videostudie. Byl popsán postup výběru vzorku a sběru výzkumných dat. Stručně byly představeny zamýšlené analýzy, jejichž výčet není konečný. Dů- 
raz byl kladen především na představení analýz zaměřených na organizační formy a fáze výuky a na didaktické řídicí styly, které byly prezentovány v kontextu organizačních forem výuky. Dále byly stručně představeny analýzy zaměřené na verbální projevy učitele a na obsahovou stránku vyučování a učení. Tím však výčet analýz zamýšlených $v$ CPV videostudii tělesné výchovy nekončí. $V$ průběhu řešení projektu se bude rozšiřovat, protože výzkumná data získaná v projektu CPV videostudie tělesné výchovy představují bohatý potenciál pro intenzivní výzkum procesů vyučování a učení tak, jak se odehrávají v reálných podmínkách současné české školy.

První krok v CPV videostudii tělesné výchovy představuje deskriptivní analýza. Tu neIze podcenit, nebot teprve na základě dobře zachycené a detailně popsané reality Ize směřovat $\mathrm{k}$ hlubšímu porozumění procesům vyučování a učení ve výuce. Následně se přistoupí k explanaci (vysvětlení) - počítá se přitom s využitím takových kategoriálních systémů a posuzovacích škál, které umožní proniknout $\mathrm{k}$ hlubším strukturám a mechanismům, jimiž jsou procesy vyučování a učení v tělesné výchově vedeny. Cílem mezioborového srovnání výuky v různých vyučovacích předmětech (fyzika, zeměpis, anglický jazyk, tělesná výchova) je identifikovat specifické rysy výuky tělesné výchovy, které vyplývají z odlišnosti učiva.

\section{Literatura}

ANDERSON, H. H. The measurement of domination and of socially integrative behavior in teachers contacts with children. In Inteaction analysis, theory, research and applications. Mass. Addison Wesley, 1967, s. 4-23.

ANDERSON, W. Videotape data bank. Journal of physical education, \& recreation, 1975 , roč. 46, č. 7, s. 31-35.

ANDERSON, W.; BARRETTE, G. Teacher behavior. In What's going on in gym. Descriptive studies of physical education classes. Monogr. 1. Motor skills. Theory into practice. Newton, 1978, s. 3-5.

ARRIGHI, M.; YOUNG, J. Teachers' perceptions about effective and successful teaching. Journal of Teaching in Physical Education, 1985, roč. 6, č. 2, s. 122-135.

CARREIRO da Costa F.; PEREIRA, P. ; DINIZ, J.; PIÉRON, M. Motivation, perception de compétence et engagement moteur des élèves dans des classes d'éducation physique. Revue de l'Education Physique, 1997, roč. 37, č. 2, s. 83-91.

CARREIRO da Costa F. ; PIERON, M. Teaching effectiveness: Comparison of more and less effective teachers in an experimental teaching unit. In WILLIAMS, T.; ALMOND, L.; SPARKES, A. (eds). Sport and physical activity. Moving towards excellence. The Proceedings of the AIESEP world convention. London : E \& FN Spon, 1992, s. $169-176$.

COSTELLO, J.; LAUBACH, s. Student behavior. In ANDERSON, W.; BARRETTE, G. (eds) What's going on in gym: descriptive studies. Motor Skills: theory into practice, monograph 1, 1978, s. 11-24.

COTHRAN, J. D.; KULINNA, P. H.; BANVILLE, D. B.; CHOI, E.; AMADE-ESCOT, Ch.; MACPHAIL, A.; MACDONALD, D.; RICHARD, J-F.; SARMENTO, P.; KIRK, D. A Cross-Cultural Investigation of the Use of Teaching Styles. Research Quarterly for Exercise 
and Sport, 2005, roč. 76, č. 2, s. 193-201.

CURTNER-SMITH, M. D.; KERR, I. D.; KUESEL, K.; CURTNER-SMITH, M. E. Pupil Behaviours in British Physical Education Classes: A Descriptive-Analytic Study. International Journal of Physical Education, 1995, roč. 32, č. 1, s. 16-23.

DARST, P. W.; MANCINI, V. H.; ZAKRAJSEK, D. B. Systematic Observation Instrumentation for Physical Education. West Point : Leisure Press, 1983.

DOBRÝ, L. Metodologické problémy výzkumu vyučovacích činností učitele tělesné výchovy. Teor. Praxe těl. Vých., 1975, roč. 23, č. 1, s. 20-29.

DOBRÝ, L. Změna činnosti učitele je hlavní podmínkou úspěchu naší školské reformy. Tělesná výchova a sport mládeže, 2007, roč. 73, č. 3, s. 8-15.

DOBRÝ, L.; SVATOÑ, V. Analýza didaktické interakce. Popis výzkumné metody a návod k jejímu použití. Praha : FTVS UK, 1977.

DOBRÝ, L.; SVATOŇ, V.; ŠAFAŘíKOVÁ, J. Analýza didaktické interakce. Manuál. Praha :FTVS UK, 1984.

DOBRÝ, L.; SVATOŇ, V.; ŠAFAŘÍKOVÁ, J. Deskripce a analýza didaktické interakce. In Utváření vztahů učitelů a žáků v socialistické škole. Praha : UK, 1981, s. 38-74.

DOBRÝ, L.; SVATOŇ, V.; ŠAFAŘíKOVÁ, J.; MARVANOVÁ, Z. Analýza didaktické interakce v tělesné výchově. Praha : Karolinum, 1997.

DOYLE, W. Paradigmes de recherche sur l'efficacité des enseignants. In CRAHAY, M. ; LAFONTAINE, D. L'art et la science de l'enseignement. Bruxelles : Ed. Labor, 1986, S. 435-481.

FREEDMAN, M. Follow-up of physical education graduates from a teacher preparation program: a descriptive analysis. Unpublished doctoral dissertation. Ohio State University, 1978.

FRÖMEL, K.; NOVOSAD, J.; SVOZIL, Z. Pohybová aktivita a sportovní zájmy mládeže. Olomouc : Univerzita Palackého, 1999.

GRANT, B. The relationship between specialist training and effective physical education teaching in the elementary school. In HOWE, B.; JACKSON, J. (eds). Teaching Effectiveness Research. Victoria, British Columbia : University of Victoria, 1985.

HOUSNER, L.; GRIFFEY, D. Teacher cognition: Differences in planning and interactive decision making between experienced and inexperienced teachers. Research Quarterly for Exercise and Sport, 1985, roč. 56, s. 45-53.

HÜBELOVÁ, D.; JANÍK, T.; NAJVAR, P. Formy a fáze ve výuce zeměpisu: metodologický postup a vybrané výsledky CPV videostudie zeměpisu. In JANíK, T.; KNECHT, P.; NAJVAROVÁ, V. (eds). Příspěvky k tvorbě a výzkumu kurikula. Brno : Paido, 2007, S. $141-156$.

HURYCHOVÁ, A. Vztahy mezi činností učitele a činností žáka ve vyučovacích hodinách tělesné výchovy. Kandidátská disertační práce. Brno : UJEP, 1983.

JANÍK, T.; MIKOVÁ, M. Videostudie: výzkum výuky založený na analýze videozáznamu. Brno: Paido, 2006.

JANÍK, T.; NAJVAR, P. Videostudie ve výzkumu vyučování a učení. Orbis scholae, 2008, roč. 2, č. 1.

JANÍK, T.; NAJVAR, P. Zkoumání procesů vyučování a učení prostřednictvím videostudie. In Orbis scholae, 2006, č. 1, s. 111-126. 
JANSA, P. Deskripce a analýza činnosti učitelů a žáků 1. stupně základní školy. In Tělovýchovný sborník. Praha: Olympia, 1987, s 175-198.

KARÁSKOVÁ, V. Profesní kompetence učitele tělesné výchovy na zvláštní škole. Habilitační práce. Olomouc : FTK, UP, 1994.

KULINNA, P. H.; COTHRAN, D. J. Physical education teachers' self-reported use and perceptions of various teaching styles. Learning and Instruction, 2003, roč. 13, s. 597-609.

MATOUŠEK, J. Aktivita žáků v závislosti na činnosti učitele tělesné výchovy. Kandidátská disertační práce. Brno : UJEP, 1984.

MIKOVÁ, M.; JANÍK, T. Analyse von gesundheitsfördernden Situationen im Sportunterricht: Methodologisches Vorgehen einer Videostudie. In MUŽíK, V.; JANÍK, T.; WAGNER, R. (eds). Neue Herausforderungen im Gesundheitsbereich an der Schule. Was kann der Sportunterricht dazu beitragen? Brno : MU, 2006, s. 248-260.

MIKOVÁ, M.; JANÍK, T. Metodologický postup CPV videostudie tělesné výchovy: analýza výuky tělesné výchovy na 2. stupni základní školy. In Svět výchovy a vzdělávání v reflexi současného pedagogického výzkumu. Sborník příspěvků XV. konference České asociace pedagogického výzkumu [CD-ROM]. České Budějovice : KPP PdF JČU, 2007a.

MIKOVÁ, M.; JANÍK, T. Návrh metodologického postupu videostudie tělesné výchovy. In MUŽÍK, V.; SÜSS, V. (eds) Tělesná výchova a zdraví pro 21. století: myšlenky, které by měly usměrňovat tvorbu školních vzdělávacích programů. Brno : MU, 2007b, s. 70-74.

MOSSTON, M.; ASHWORTH, s. Teaching Physical Education. 5. vyd. San Francisco : Benjamin Cummings, 2002.

MUŽík, V. Příspěvek ke zkvalitnění učitelského vzdělávání v tělesné výchově. Česká kinantropologie, 1997, roč. 1, č. 1, s. 67-73.

MUŽÍK, V.; HURYCHOVÁ, A. K novému pojetí didaktiky tělesné výchovy. Brno : MU 1994.

MUŽÍK, V.; JANÍK, T. Tělesná výchova z pohledu absolventa základní školy. In MAŇÁK, J.; JANÍK, T. (eds) Absolvent základní školy. Brno : MU, 2007, s. 197-214.

MUŽíK, V.; UHLÍŘ, Z. Ovlivňování vyučovací činnosti učitele tělesné výchovy na 1. stupni základní školy. Teor. Praxe. těl. Vých., 1989, roč. 37, č. 12, s. 724-731.

NAJVAR, P.; NAJVAROVÁ, V. Metodologický postup CPV videostudie anglického jazyka: analýza výuky anglického jazyka na 2. stupni základní školy. In Svět výchovy a vzdělávání v reflexi současného pedagogického výzkumu. Sborník příspěvků XV. konference České asociace pedagogického výzkumu [CD-ROM]. České Budějovice : KPP PdF JČU, 2007.

NAJVAR, P.; NAJVAROVÁ, V.; SOBĚSLAVSKÁ, V.; ŠEBESTOVÁ, S.; VLČKOVÁ, K.; ZERZOVÁ, J. CPV videostudie anglického jazyka: sběr dat a zamýšlené analýzy. Orbis scholae, 2008, roč. 2 , č. 1.

PIÉRON, M. Analyse de l'enseignement des activités physiques. Bruxelles : Ministère de I'Education Nationale et de la Culture française, 1982.

PIÉRON, M. Research on teacing physical activities and sport: paradigma and selected results. Ital. J. Sport Sci, 2005, roč. 12, č. 1, s. 4-17. 
PIÉRON, M.; DOHOGNE, A. Comportements des eleves dans des classes d'education physique conduits par des enseignants en formation. Revue de l'Education Physique, 1980, roč. 20, č. 4, s. 11-18.

PSOTTA, R. Analýza intermitentní pohybové aktivity. Praha : Karolinum, 2003.

Seznam základních škol v České republice poskytnutý Ministerstvem školství, mládeže a tělovýchovy ČR dne 16. 9. 2006.

SILVERMAN, s. Research on teachning in physical education. RQES, 1991, roč. 62, S. 352-363.

StatSoft, Inc. (2006). STATISTICA (data analysis software system), version 7.1. www.statsoft.com.

SÜSS, V.; MATOŠKOVÁ, P.; ŠTEFANŠÍKOVÁ, K. Objektivní a subjektivní hodnocení vybraných forem chování učitele ve vyučovacích jednotkách tělesné výchovy. In DOBRÝ, L.; SÜSS, V.; ČECHOVSKÁ, I. (eds). Sborník ze semináre "Svatoňova Stráž", konaného 17. - 19. ríjna 2003 v Daňkovicích. [cit. 10. 1. 2008]. Dostupné na: <http://www.ftvs.cuni.cz/knspolecnost/pedagogicka/sbornik2003.php>

SVATOŇ, V. Konfigurace proměnných didaktické činnosti v gymnastice se zřetelem k uplatnění didaktických řídících stylů. Závěrečná zpráva DÚ RÚMŠ IX-05-03. Praha : FTVS UK, 1990.

SVOBODA, B.; KOCOUREK, J. Výzkum osobnosti a vyučovací činnosti učitele tělesné výchovy. In Tělovýchovný sborník. Praha : Olympia, 1987, s. 48-74.

ŠAFAŘíKOVÁ, J. Využití analýzy didaktické interakce při výzkumu rozhodování učitele. In Osobnost učitele tělesné výchovy. Olomouc : PF UP, 1974, s. 193-200.

TELAMA, R.; PAUKKU, P.; VARSTALA, V.; PAANANEN, M. Pupil's physical activity and learning behaviour in physical education classes. In PIÉRON, M.; CHEFFERS, J. (eds) Studying the teaching in physical education. Liege : AIESEP, 1982, s. 23-35.

VILÍMOVÁ, V. Didaktika tělesné výchovy. Brno : Paido, 2002.

WARD, P.; BARRETT, T. A Review of Behavior Analysis Research in Physical Education. Journal of Teaching in Physical Education, 2002, roč. 21, s. 242-266.

WIDMER, K. Zum Problem des Lehrer - Schüller - Verhaltnisses im Sportunterricht. In BEYER, E.; RÖTHIG, P. (eds). Beiträge zur Gegenstandsbestimmung der Sportpädagogik, 1976, 13-43.

Tato studie vznikla za podpory MŠMT ČR v rámci projektu „Centrum základního výzkumu školního vzděláváni" s registračním číslem LC06046. 